\title{
Legal Aspects of Internet Banking in Contexts of Internal and International Laws
}

\author{
Nariman Fakheri ${ }^{1}$, Zahir Jafarniya ${ }^{2}$, Seyed Gani Nazari ${ }^{3}$ \\ ${ }^{1}$ Assistant in PAYAME NOOR University, IRAN \\ ${ }^{2}$ Master of International Law, IRAN \\ ${ }^{3}$ Master of Criminal Law and Criminology, IRAN
}

\begin{abstract}
The modern world deals with great changes on communication of information and development of new technologies of communication and information, making it inevitable to apply new management, economic, political, and legal methods and strategies. The new information and communication that is the basis of management in the modern world requires proper mechanisms and infrastructures in order to make the development of business and good environment for entrepreneur possible. One of the most important infrastructures is internet banking. Arising any issue, whether political, social, economic, or cultural, has consequences associated with different internal or international outcomes, regardless of their positive or negative results. Since financial issues have been always the most challenging issues in human societies, internet banking is dealt with economic issues in a different and new way and hence, it may include regulations to meet, internally or internationally, the legal needs of clients and custodians and contribute to developing this technology further. Global central bank thinking and a uniform treaty for internet banking with strategic rules and regulations to resolve the financial disputes arising from internet banking is an instruction for pragmatists in reaching a global uniform procedure, which is considered as the most important outcome of modern communication, i.e. internet banking. Drafting and adoption of the International Convention on internet banking under considerations of the United Nations Commission on International Trade Law through instructions and procedures of the central bank providing two conditions of goodwill and safety is an introduction for the realization of internet banking, which needs the contribution and cooperation of all countries including Iran. Internet banking may be misused and have harmful consequences for economy as much as it can contribute to develop economic, financial and banking activities. Aiming at improving internet banking and treating against violators and maintaining the clients' values, legal rules, either internal or international, are to maintain the clients' rights on the one hand and contribute to strengthening the foundations of this new economic technology on the other hand. In this context, this paper aims at study the legal aspects of internet banking in contexts of internal and international laws and explores the related rules with this technology briefly.
\end{abstract}

Keywords: Electronic banking, Internet banking, Competent court in internet banking

\subsection{Electronic banking}

\section{Definitions and Concepts}

"Providing banking services through a publically accessible computer network (Internet or Intranet) that is highly secured" or" providing customers access to banking services by secure intermediaries and without physical presence". The transformation of a banking system and turning to electronic services depends on the state economic policies and providing legal and administrative frameworks as well as developing information and communication technology. Obviously, changes in any country depend on the culture of that country and the changes in internet banking is not an exception. Computer software and software systems are used in electronic banking.

Generally, electronic-banking is banking operations through centralized computer systems, networks with widespread accessibility, and the lack of time and space constraints and information security (using credit cards, ATMs, global union services, interbank financial telecommunications, satellite communication lines, banking at home, software, and remote banking are all services by electronic banking). It is said that electronic banking is using electronic devices in offering banking services, which is in turn classified under electronic funding. Providing a communication network between the clients and banks at internal or international levels is the starting point for electronic banking.

\subsection{Internet banking}

Internet banking is a part of electronic banking; indeed, it deals with banking operations by World Wide Web. It includes providing services to clients through Internet so that they can organize or change their accounts or invest and do other operations. 


\subsubsection{Digital (electronic) signature}

It is one of the best secure practice in internet banking, which is as old as electronic business and is sometimes in a general sense referred to as electronic signature and is the result of cryptography (the science that solve the codes of a text by mathematics, software and hardware methods and the receptor can use the same algorithm to encode them). Any sign is attached or connected logically to the data of that message, which is used for identifying the signer of the "data of message".

\subsubsection{Internet Service Provider (ISP)}

Internet is a global network of communication networks, has become a powerful communication tool in internal, regional, and international affairs. In users' views, ISP serves as a bridge to connect to the Internet. In this context, users can access to what is accessible and allowable in the World Wide Web, share their information and send or receive messages in different forms. ISP is efficient in internet banking. Connection with internet is canceled without ISP since it serves as a bridge between the content and the receiver of information; in fact, it is considered as a network interface.

\section{Legal Aspects of Internet Banking (in Contexts of International Laws)}

\subsection{The rule of law over the international internet banking}

Many of the issues that the international law tries to resolve peacefully for developed countries (such as internationalizing the government contracts and governmental rules adjustment in private contracts) are seriously considered in internet banking.

When a description of a relationship comes into effect, the governing law determines the scopes; if the relationship between two parties outside the national scopes and is connected with one or more countries, due to the involvement of an international element, we have to determine the governing rule. The internationalization of relations arises problems cannot be viewed from internal law; these problems may be dealt with internet banking because of its special nature. In general, one of the main objectives of internet internationalization is predicting the communication and bank transactions beyond the borders.

International internet banking has requirements; if they are not met, this structure may move to a dead end or face with serious challenges in terms of lawlessness. It is of great importance to know about the governing rule in the relations of internet banking and the contribution of contracts in this area.

The governing rule in internet banking, like in the other areas, refers to legal description and analysis of the interactions in internet banks and dispute resolution. Obviously, the specific provisions should set criteria for action In this regard; otherwise, if the court enforces its regulations unrelated to the topic or various regulations from different countries have been used, decision-making would be difficult or unrelated to the realities of the issue. Generally, it is believed that "dispute-resolution regulations in national legal systems, whether in the form of internal legislation or through international treaties do not tend to accept out of national (transnational) selections and have rigid and strict rules".

\subsubsection{Peremptory rules of international internet banking}

Doing any business activity (including banking) requires knowledge about that. This results in enforcing regulations by banks, contributing to national economic development and avoiding harms at the internal and international levels.

The peremptory principle is about the laws and regulations adopted and implemented on monetary affairs and banking except in private banking contracts in which the rules between the parties are peremptory as long as they are not opposed to the peremptory law.

On banking, the government enforces regulations to protect the interests of people involved in such transactions, and in macro levels, to protect the society. If internet banking can frequently continue its illegal activities, the society and the economy will be certainly influenced.

Implementing the peremptory rules on internet banking, electronic financed contracts between traders is of greater consideration. The consequences of failure to implement the peremptory rules in internet banking can be reflected directly in turmoil in internal economy, or international criminal acts such as online money laundering, and the financing of terrorism through the global network. Since if there was no rule governing the virtual space or countries were not willing to cooperate, internet would become a way for the monetary values trafficking and fraud to money and banking rules.

However, the Bank for Reconstruction and Development has predicted financial supports in order to prevent such crimes, and different countries have passed internal laws before the development of internet banking. The general remind of these regulations recognized as "peremptory rules" in banking law is required since the institutions or organizations that do internet banking can follow them to develop their activities.

"The principle of good will" is another important rule that banks are required to follow. It requires the banks to express explicitly their strengths and weaknesses to their clients and announce any problem or crime to 
clients and police. Generally, the national interest should be considered as "bases" in interpreting the regulations on internet banking. Preventing money laundering and other similar crimes and immethodical withdrawal is the general policy in banks, which should be considered in regulating rules in different areas.

\subsection{Competent court in international internet banking}

In personal relationships such as internet banking contracts or mandatory responsible in this area, as parties have the right to choose the enforceable regulation and only the limitations of the peremptory rules of good will and consumer rights are required for such choices, they have right to choose the competent court for their relationship.

It is stipulated in standard internet bank contracts that the court, where the internet banking is established, has the jurisdiction. In these forms of relations, the parties can deviate from the jurisdiction of the state courts and put their contractual liabilities before or after dispute and the issues of non-contractual liabilities after the realization, under the jurisdiction of institutional or ad hoc tribunal arbitration reference. Therefore, if the required elements for a jurisdiction over the crimes in internet banking are provided, that court is inevitable competent and reject this authority by mutual consent of the parties or claim of a court from another country.

\subsubsection{Competent court's discretion in international internet banking}

Competency for hearing requires automatically fast, open, fair trial that is in accordance with law; otherwise, at least the international political consequences will be the result. On internet banking, like the other topics, the principle is that the court at venue has authority and on civil issues, the domestic court (forum domicile) has this authority.

These two principles are, internally and internationally, the bases of choosing the city (jurisdiction) and the country in which the court has authority. Considering these facts and principles, the judgmental procedures from different countries indicate that governments have developed their authorities on internet banking crimes and generally, criminal acts in virtual space, for protecting from national interests and people's rights.

There have been suggested different views on the competent court's discretion and resolution of disputes arose from internet banking transactions. Views such as the authority of the court in "location of contract", "location of bank account", or "location of the branch" as well as traditional banking have been suggested in internet banking system. Regarding authority, it is totally believed that the court in which the contract has been written, through websites, emails, or other communication equipment is competent.

\subsection{The role of Central Bank in international internet banking}

Online business payments need a mediator that is internationally reliable and protects the national interests at international level, and hence, the central bank or an institution at the same status usually plays such a role at the transnational level. The international internet banking is usually established to fulfill the commercial purposes.

The contribution if the Central Bank in this process has been decreased and the developed countries, such as the US. or European Union, whose currencies have international values neglect the outcomes of international transfers of currency on their internal economy. In this context, the same procedures dominate over their banking relations with developing countries.

The European Union as the symbol of international and, of course, regional coordination has predicted measures to accelerate the Central Bank practices of the EU members to transfer money and settlement in the EU. However, as it has been said internet banking may require an institution with the same rank, i.e. Central Bank, which has been only predicted in the EU.

Obviously, the global Central Bank's achievement requires coordination and interaction with monetary institutions and internet banking. The global central bank, without guarantees and executive power for its decisions, is merely a guidance body and will fail from achieving the higher goals of safe banking.

\section{Legal aspects of internet banking (in contexts of internal laws)}

It is not so long since the Iranian could have access to the Internet. There are different obstacles to the development of the Internet in Iran; for instance, high cost, low speed, problems in connectivity, lack of knowledge and skills to use it, political and economic sanctions (e.g. some websites are blocked for the Iranian users).

Banking is a more economic concept and the experience has shown that electronic-internet banking is not separate from economies of countries. Iranian do not view internet as a necessity but it is as a luxury technology. Iran needs an economic planning; the technical and information infrastructures need to be provided and then the cultural aspects and internet banking may be considered. 


\subsection{Internal regulations on internet banking}

The origins of legislation in the relation between banks at national and international levels undoubtedly are different. Internal financial relations, maintaining the public rights and interests in inter-banking interactions and monetary and currency issues prohibit making any private agreement as valid.

Unfortunately, the international documents on business and transactional payments deal rarely with internet banking. This may be due to this fact that most of the regulations are old and had been established before modern ways of payment.

\subsubsection{Taxation regulations in internal internet banking}

Obtaining tax from online businesspeople is difficult due to: 1. theoretically, accounting system and recording histories in internet has no specific mechanism and anyone pays tax according to his/her own documents; 2. lack of a specific location for the internet bank for all or most of clients.

Since living location is a place based on which tax is obtained, if this place is not known, there is no competent authority to obtain tax even though the identity and online activities of the person are known. These problems can be added to the problems stated by the Economic Development and Cooperation Organization, as global standards in electronic business.

According to the report, 1. The internet websites cannot be regarded as permanent habitant. 2 . Agreement on an internet website cannot be regarded as permanent habitant for an institution, through which it performs its business. 3 . The internet services provider is not allowed to be regarded as the representative of the businessperson who uses the services, except in unusual conditions, and hence, the ISP location is that person's permanent location of habitant.

\subsubsection{Obeying the religious rules in internal internet banking}

The Muslims, sometimes, doubt if internet banking is religiously true or not. Since Iran is an Islamic country, it should be said that the Muslim scholars (Malaysian) emphasized on creative and innovative aspects of Islam and is superior, in this regard, to other religions and found no problem with internet transactions.

The sequence of offer and acceptance, the impossibility of suspending the composition of contracts and separate interests of the contracting parties in swap transaction in the relation between the internet bank and client are included in general rules of contracts in Islamic law and the modern banking has caused no change in this regard. Implementing the Islamic bank regulations in transactions, those who are willing to use internet banking services under Sharia are not allowed to obtain any compensation as "usury" is haram.

In this context, Islamic internet banking requires the contracts between bank and client be under one of the following religious contracts: limited partnership (Mudaraba), reward (Jo'aalah), or endowment (Vadi'ah). According to Article 11 (1) (a) Islamic Banking Act, if an institution that operates as an Islamic bank does operations against mandated Islamic rules, its license will be denied.

\subsection{Insurance of internal internet banking}

Internet banking copes with risks caused by modern nature of communication mean and consequently, lack of knowledge about some risks, and risks associated with monetary and banking operations. If, in any reason, fails to fulfill services and obligations, it leads to condition known as "risk-making".

Some risks may be the result of computer errors and generally they may be the factors with no relation with caution and control. Though it is impossible or practically hard that all banking operations be under insurance, some ideas can be acceptable in the relations between banks and the internet transactions require interbank contracts. In this regard, bankruptcy of banks, due to losses caused by disruptions in online payments, can be prevented through involving all the contracting banks. Resolving the problem of need for risk calculation, wasting bank time, or lack of cooperation among banks when loss occurs, we may adopt a procedure through which the "Loss Distribution Fund" can be established. Aiming at protecting the consumer rights and preventing unpredictable losses, this fund does not compensate for entire loss.

In fact, each of victims can be supported in proportion to the loss and as much as the fund allows. The fund should be established in the Central Bank of Iran, and the instruction on management and payment of losses should be provided according to the regulations mentioned above.

\section{Conclusion}

Internet banking is part of development in banking and the outcome of electronic banks and other ideas including generalization of economy. Indeed, internet banking is an advanced from of electronic banking can go beyond borders and challenges countries with important issues like protecting the national economy at macro level. Though following the same legal rules on different aspects at internal or international levels, it may depend on special analyses of internal or transnational rules in terms of the issue. At international level, internet banking has opened new horizons for rules that cannot be analyzed by relying on rules on private rights. 
When there are legal limitations and penal enforcement against transnational banking, the global network of communication cannot be excused to escape from law. At internal level, it can be claimed that electronic banking regulations are enforceable, except on security issues that need to be discussed in details, and only big transactions should be of greater caution. The problems such as the location of contracting, the place of implementing commitments, terms for claiming compensation can be resolved by making the contractual relations clear, minimizing the disputes in the future.

A question here arises how the Iran's future approach towards the important issue of internet banking will be drawn, whose "international" version is of great importance.

Iran's future approach towards international internet banking is too economic since this issue is very important. In fact, governments are largely coordinated in terms of rules and regulations and the global village is increasingly shrinking and internet banks offer banking services more than ever through standard contracts in which customers' freedom and right to choose are emphasized. Therefore, regional currency rather than national currency has been suggested.

Changes in communication space has been influenced by modern communication means, and has challenged organizations and people, before governments, to do business in the new space. All changes require agreements between governments at international level and passing law at internal level. These agreements should be under Constitution if their political-economic procedures are legitimized.

\section{Practical and executive strategies}

In contracts between internet banking and client, the negotiations that are effective and are regarded as a way to respect the clients should be possible; the court cannot interpret the contract arbitrarily or broadly. The additional contract is required to be interpreted in favor of a third party who is not involved in it, due to the influence and control of the contractor.

The practical procedure has been developed recently on electronic contracts between bank and clients is that the internet bank stipulates in the contract that the location of contract is bank and the contract comes into effect when the agreements are done and the deposit is paid to the client.

Despite growing interest in internet banking, ambiguity in the nature or lack of information have made doubts in dealing with this type of banking, especially those in middle or lower classes of society; they are afraid of unsafety or disclosure of their financial accounts and may not believe in internet bank as a good way to achieve their goals. "Preventive measures", for some, albeit with financial or time costs, are rigid beliefs and what can change such traditional beliefs to accept internet banking is clarification of different aspects of internet banking. Since bank is associated with clients, this matter is of great importance.

Since the contracting human party cannot be included under technical regulations such as "encryption", the rules might be violated; therefore, banks should consider measures to warn the clients on the one hand, and to guarantee their security on the other hand.

If any disagreement occurs between bank and client, the contract and the provisions are the criteria for action. Because, the true and common intentions of the parties should be considered to evaluate the form and provisions of the contract and should not be bound to terms or titles used mistakenly by the parties to keep secret the true nature of the contract. On the crimes against internet banking, it should be noted that prevention or prosecution requires organizations, institutions, internal legal and real persons and governments at international levels; realizing this matter, the required executive measures, according to the future penalty for computer crimes, should be considered in the country.

Those parts of crimes against internet banking, which have not been subject to penalty due to lack of history in the current law, should be criminalized after considering the social and economic consequences.

The most important function of international cooperation for the future internet banking is uniformity in regulations and rules on this issue. This uniformity has been achieved to some extent in criminal aspects of internet banking, including money laundering. Uniformity in international regulations on internet banking in different aspects of contracts and civil liabilities is not far-fetched. Particularly, since the issues such as management, safety strategies, information exchange, and multilateral business contracts are common interests in countries, unlike issues like money laundering, which are political at macro levels. Therefore, international uniformity in such common interests can legalize them as well.

As the governments' failure to cite the restrictive internal regulations on international trade can be accepted through the necessity of good will in international relations, everyone should do his best to use the expertise and precautions to provide the national interests while agreeing with international internet banking infrastructure development contracts. Failure in choosing the dominant rule in the relation between bank and client requires the Iranian court to follow the Iranian Law, except for the cases in which the law is not related or has predicted no special regulation to solve that problem.

On internet banking, the principle is that the court where the crime has occurred and the court where the domicile of the claimant is have authorities to jurisdiction for crimes and civil issues, respectively. This 
principle should be considered at both internal and international levels to recognize the city (jurisdiction) and the country whose court have the authorities for jurisdiction.

The dominant rule in non-contractual liabilities in internet banking has to be a related and predictable one. Achieving this goal, the recognition criterion may be changed from the location of loss to a rule with more relativity in order to protect the rights of consumer who used the services of online internet bank. Realizing the true policy-making role of the Central Bank on internet banking, two functions should be considered for this institution: supervision of all banking operations and regulating the rules of currency transactions.

Iran follows the rules of Islamic banking, and it should be considered that operations in internet banking require protection of regulations such as "interest-free banking regulation" and development in internet operations should not disrupt the implementation of these regulations.

The internet banking operations have to be in the form of public joint stock company under monetary and banking rules of Iran though the banks can have the license for such operations.

An unbiased supervisor, on issues of internet banking, should predict the cautions to prevent crimes and protect consumer rights; it seems that, except for crimes and violations relevant to law enforcement and judicial institutions, the Central Bank is an appropriate supervisor.

On internet banking in Iran, like in other banks in the world, the unity between the supervisor (e.g. Central bank) and regulator should be accepted. Since rapid exchange of information in banking operations allows the Central bank to notify the other involved banks about problems and challenges in internet banking, especially in the early years of this form of banking establishment. The internet banking operations have to be in the form of public joint stock company under monetary and banking rules of Iran though the banks can have the license for such operations.

Two factors, i.e. skill and precaution, as the main factors in internet banking should not be ignored. In fact, internet banking would be distinct from its general term if it predicts skill and precautions (in conventional forms of civil liabilities).

\section{References}

[1]. Abbasinejad H. Mehrnosh M. (2010). Electronic banking. Samt Publications. Tehran.

[2]. Abdollahi M. Shahbaziniya M. (2010). Reliable information systems in e-commerce law. Journal of Legal Research. 16.

[3]. Allahyarifard M. (2004). E-banking services and the administrative needs of its comparative operating expenses, various banking services. Monetary and Banking Research Institute. Tehran.

[4]. Avovoanu, Electronic banking and the Law'London, 1999, PP. 212-219.

[5]. Delta 'George‘Willamette Journal of Internatinal Law and Dispute Respute Resolution Vol.7،2000

[6]. Elsan M, Yamchi D. (2002). Computer nature and legal aspects of digital signatures. Quarterly Journal of Judicial Law Views, 30.

[7]. Elsan M. (2007). The digital signature on documents in an electronic form. Legal Monthly Association of notaries. 55.

[8]. Elsan M. (2014). Low of Internet Banking. Monetary and Banking Research Institute. Tehran.

[9]. Elsan M. (2015). Cyberspace Law. 1 ed. Shahre Danesh Publications. Tehran.

[10]. GordomLesliea‘Banking on Faith ‘American Bar Association Journal‘Vol.91‘2005.

[11]. Gosnell C. (1988) Miami Law Review. Canadian Business Law Journal, 29.

[12]. GROUP Oftem/ReportonConsolidationin the Financial sertor 2007. Sakabdeen and etal‘op.Cit‘p.304.

[13]. Haubrich by Joseph G(1996).combining Bank supervision and Monetary Policy, WWW.Clevelandfead.org. UNCTAD ECommerce and Development Repert 2001 p .168.

[14]. Hoenig‘thomasm‘Federal Reserve Bank of Kansas city Economic Review‘1996. O,Driscoll‘Gerald‘Catogornal‘Vol.7 No.361988.P.661-675.

[15]. Katozyan N. (2014). General rules of contract. Corporation Publications. Tehran.

[16]. Luftman, Douglas B, Defamation Liability for online services: The Sky is not Falling, George Washington Law Review, Vol. 65 (6), 1997. p. 1096.

[17]. Magnin, Cedric J. (2001) "The Telebanking Contract In Swiss law," ILSA Journal of International \& Comparative Law: Vol. 8 : Iss. 1 , Article 3.

[18]. Marcucci‘Jacgueline‘Nova law Review‘Vol.23‘1999.p.755

[19]. Mehdi Khosrow-Pour. Encyclopedia of Information Science and Technology. USA. 2008. P. 432.

[20]. Mokey‘Ul rich and Hans-Jurgen‘Thenorth American Journal of economics and Finance‘Vol.7(2)‘1996.

[21]. Nikbakht HR. (2004). Issues raised in the law governing the contract. Journal of Legal Studies. 39.

[22]. Schooner‘Heidi Mandanis‘Brooklyn Internatinal Law Journal‘Vol.28‘2002-2003.

[23]. Sean M. O'Connor. The De Minimis Exemption of Stored Value Cards from Regulation E: An Invitation to Fraud.Richmond jounal of law and Technology. Vol V'ISSUE 2،Winter1998.

[24]. Seyed Javadin, R. Saghatchi, M. (2006). Electronic banking and evolution in Iran. Tadbir Monthly. 170. 